\title{
Genetic diversity of the Neotropical tree Hancornia speciosa Gomes in natural populations in Northeastern Brazil
}

\author{
H.J. Jimenez ${ }^{1}$, L.S.S. Martins ${ }^{1,2}$, A.V.V. Montarroyos ${ }^{3}$, J.F. Silva Junior ${ }^{4}$, \\ A.L. Alzate-Marin ${ }^{5}$ and R.M. Moraes Filho ${ }^{3}$ \\ ${ }^{1}$ Programa de Pós-Graduação em Agronomia/Melhoramento Genético de Plantas \\ Universidade Federal Rural de Pernambuco, Recife, PE, Brasil \\ ${ }^{2}$ Departamento de Biologia, Universidade Federal Rural de Pernambuco, \\ Recife, PE, Brasil \\ ${ }^{3}$ Departamento de Agronomia, Universidade Federal Rural de Pernambuco, \\ Recife, PE, Brasil \\ ${ }^{4}$ Empresa Brasileira de Pesquisa Agropecuária, Aracaju, SE, Brasil \\ ${ }^{5}$ Programa de Pós-Graduação em Genética, \\ Faculdade de Medicina de Ribeirão Preto, Universidade de São Paulo, \\ São Paulo, SP, Brasil \\ Corresponding author: R.M. Moraes Filho \\ E-mail: romulommfilho@yahoo.com.br
}

Genet. Mol. Res. 14 (4): 17749-17757 (2015)

Received August 5, 2015

Accepted October 7, 2015

Published December 21, 2015

DOI http://dx.doi.org/10.4238/2015.December.21.48

ABSTRACT. Mangabeira (Hancornia speciosa Gomes) is a fruit tree of the Apocynaceae family, which is native to Brazil and is a very important food resource for human populations in its areas of occurrence. Mangabeira fruit is collected as an extractive activity, and no domesticated varieties or breeding programs exist. Due to a reduction in the area of ecosystems where it occurs, mangabeira is threatened by genetic erosion in Brazil. The objective of this study was to characterize and evaluate the genetic diversity of 38 mangabeira individuals collected from natural populations in Pernambuco State using inter-simple sequence repeat (ISSR) molecular markers. The ISSR methodology generated a total of 93 loci; 10 were monomorphic and 83 were polymorphic. The average number of loci per 
primer was 15.5, ranging from 9 (\#UBC 866) to 21 (\#UBC 834). The results showed a high level of genetic diversity (0.30), and found that only around $30 \%$ of genetic variability is distributed among populations $\left(G_{\mathrm{ST}}=0.29, \Phi_{\mathrm{ST}}\right.$ $=0.30)$, with the remainder $\left(\Phi_{\mathrm{CT}}=70 \%\right)$ found within each population, as expected for forest outcrossing species. Estimates for historic gene flow (1.18) indicate that there is some isolation of these populations, and some degree of genetic differentiation.

Key words: Mangabeira; Apocynaceae; Genetic resources; Molecular markers

\section{INTRODUCTION}

The Apocynaceae family is widely represented in Brazil, with about 850 species and 90 genera (Souza and Lorenzi, 2005). The Hancornia genus is monospecific, constituted by Hancornia speciosa Gomes. Known as mangabeira, $H$. speciosa is a fruit tree that is native to Brazil, with great potential for commercial exploitation due to its nutritional characteristics. Its fruit is consumed fresh or used for the preparation of juices and ice cream, and is of great importance to human populations in its area of occurrence (Almeida et al., 1998; Silva Júnior and Lédo, 2006; Moura et al., 2011). It is a medium-sized tree, ranging from 2 to $15 \mathrm{~m}$ in height, with an irregular canopy, and twisted and highly branched stems. It frequently develops in poor, sandy soils, predominantly in the Cerrado region and on coastal plains. As is common among the Apocynaceae family, the whole plant produces latex. The plant exhibits opposite leaves, simple and petiolate, produces inflorescences with 1-7 white colored flowers, and its fruits are rounded with yellow exocarp and red spots, typically containing 2-15 seeds of 7-8 mm (Soares et al., 2005).

This species is found in most Brazilian regions, from the Amapá State in the North region, to São Paulo State in the Southeast region; therefore, exploration has been most intense in the Northeast region. Due to a reduction in the size of the mangabeira tree ecosystem, it now represents one of the fruit species most threatened by genetic erosion in Brazil (Moura et al., 2011). However, despite its importance, there are currently no established commercial varieties. The production of this crop is mainly extractive, and is observed in a few organized orchards for commercial use (Lederman et al., 2000; Silva Junior and Ledo, 2006; Ganga et al., 2009). Mangabeira is described as allogamous and self-incompatible, which contributes to high genetic variability among its seeds (Darrault and Schlindwein, 2006).

Studies on the genetic variability of existing $H$. speciosa populations are scarce. Knowledge of the genetic structure of natural populations is essential for their domestication and improvement, and in sampling for germplasm banks, since it can directly affect the long-term viability of populations (Moura et al., 2011). Due to the area of the Atlantic Forest and Cerrado being reduced, where these species occur, it is of extreme importance to identify, collect, preserve, and characterize the available mangabeira genetic resources. These resources will be essential for breeding programs, which may result in the identification and selection of superior genotypes adapted to different ecosystems, which have resistance or tolerance to major diseases and pests, as well the selection of varieties with agronomic and technological characteristics of interest for commercial exploitation (Silva Junior and Ledo, 2006).

Molecular markers have been used frequently in studies of genetic diversity in several plant species (Kumar, 1999; Wünsch and Hormaza, 2007). DNA markers based on PCR using nonspecific primers have become extremely popular, since they do not require sequence information on the species studied, and are useful in studies of genetically unknown species, as occurs in most 
forest trees (Nybom, 2004). In this context, dominant markers, such as inter simple sequence repeats (ISSRs), are useful tools in studies of genetic diversity and structure (Zietkiewicz et al., 1994).

Therefore, this study aimed to characterize the genetic diversity of 38 individuals from natural populations of $H$. speciosa in northeastern Brazil in order to investigate their genetic relationships and to contribute to the in situ and ex situ conservation of this species.

\section{MATERIAL AND METHODS}

Leaf samples were collected from $38 \mathrm{H}$. speciosa individuals (Figure 1) from natural populations in the coastal region of Pernambuco State, Brazil. Thirteen individuals were collected in the regions of Tamandaré and Praia dos Carneiros (1), 12 individuals in the region of Itamaracá (2), and 13 individuals in the regions of Nazaré and Praia do Paiva (3) (Figure 2 and Table 1).

DNA was extracted from $\sim 1 \mathrm{~g}$ leaf tissue according to the method described by Murray and Thompson (1980). Quantification of DNA was performed by visual comparison on $0.8 \%$ agarose gel using standard concentrations of $15 \mathrm{ng} / \mu \mathrm{L}$.

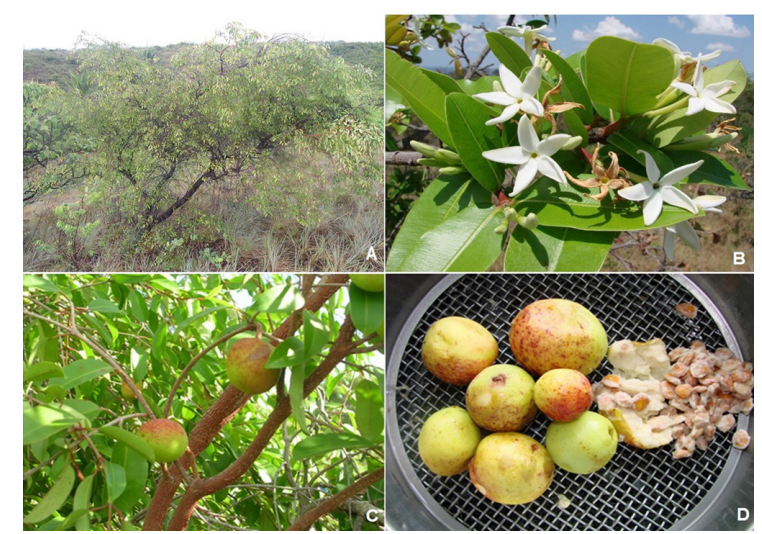

Figure 1. Neotropical tree Hancornia speciosa (A), flowers and leaves (B), tree with fruits (C), fruits and seeds (D) (Source: Jimenez H and http://www.agencia.cnptia.embrapa.br).

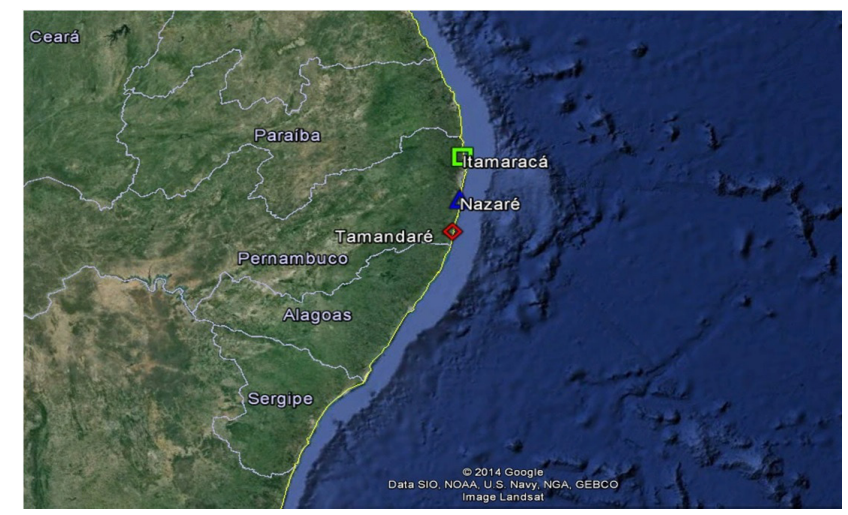

Figure 2. Origin regions of the 38 sampled Hancornia speciosa individuals from Pernambuco State, Brazil (Source: Google Earth). 
Table 1. Individuals of Hancornia speciosa used in the study.

\begin{tabular}{|c|c|c|c|}
\hline Region & Origin & Individuals & Longitude/Latitude \\
\hline \multirow[t]{2}{*}{1} & Tamandaré & $\begin{array}{l}\operatorname{Han} 1, \operatorname{Han} 2, \operatorname{Han} 3, \operatorname{Han} 4, \operatorname{Han} 5, \operatorname{Han} 12, \operatorname{Han} 13, \\
\operatorname{Han} 16, \operatorname{Han} 17, \operatorname{Han} 18, \operatorname{Han} 19 \text { e } \operatorname{Han} 20\end{array}$ & $35^{\circ} 5^{\prime} 53^{\prime \prime} \mathrm{W} / 8^{\circ} 44^{\prime} 27^{\prime \prime} \mathrm{S}$ \\
\hline & Praia dos Carneiros & Han 9 & $35^{\circ} 5^{\prime} 44^{\prime \prime} \mathrm{W} / 8^{\circ} 42^{\prime} 31^{\prime \prime} \mathrm{S}$ \\
\hline 2 & Ilha de Itamaracá & $\begin{array}{l}\operatorname{Han} 21, \operatorname{Han} 22, \operatorname{Han} 24, \operatorname{Han} 26, \operatorname{Han} 28, \operatorname{Han} 30, \\
\operatorname{Han} 31, \operatorname{Han} 32, \operatorname{Han} 35, \operatorname{Han} 36, \operatorname{Han} 37, \operatorname{Han} 38\end{array}$ & $34^{\circ} 51^{\prime} 0^{\prime \prime} \mathrm{W} / 7^{\circ} 48^{\prime} 42^{\prime \prime} \mathrm{S}$ \\
\hline \multirow[t]{2}{*}{3} & Nazaré & $\begin{array}{l}\operatorname{Han} 42, \operatorname{Han} 43, \operatorname{Han} 46, \operatorname{Han} 47, \operatorname{Han} 50, \operatorname{Han} 54, \\
\operatorname{Han} 55, \operatorname{Han} 56, \operatorname{Han} 57, \operatorname{Han} 58, \operatorname{Han} 59, \operatorname{Han} 60\end{array}$ & $34^{\circ} 57^{\prime} 19^{\prime \prime} \mathrm{W} / 8^{\circ} 20^{\prime} 37^{\prime \prime} \mathrm{S}$ \\
\hline & Praia do Paiva & Han 48 & $34^{\circ} 57^{\prime} 22.77^{\prime \prime} \mathrm{W} / 8^{\circ} 16^{\prime} 30.83^{\prime \prime} \mathrm{S}$ \\
\hline
\end{tabular}

A set of six primers was used and the amplification reactions were performed in a final volume of $25 \mu \mathrm{L}$ containing $10 \mathrm{mM}$ Tris- $\mathrm{HCl}$ at $\mathrm{pH} 8.0,50 \mathrm{mM} \mathrm{KCl}, 2 \mathrm{mM} \mathrm{MgCl}, 100 \mathrm{mM}$ dNTPs, $1 \cup$ Taq DNA polymerase, and $25 \mathrm{ng}$ DNA primer at $0.4 \mathrm{mM}$. Amplifications carried out in an Eppendorf Mastercycler thermocycler were performed as follows: Initial denaturation at $95^{\circ} \mathrm{C}$ for $15 \mathrm{~min}$, followed by $30-35$ cycles of denaturation at $94^{\circ} \mathrm{C}$ for $30 \mathrm{~s}$, annealing temperature specific for each primer for $45 \mathrm{~s}$, extension at $72^{\circ} \mathrm{C}$ for $2 \mathrm{~min}$, and a final extension at $72^{\circ} \mathrm{C}$ for $7 \mathrm{~min}$ at the end of the amplification cycles (Table 2).

The amplification products were separated by electrophoresis under non-denaturing conditions on $8 \%$ polyacrylamide gels. The amplified fragments were detected by silver-staining $(20 \%)$ according to the method described by Sanguinetti et al. (1994). Allele size was determined by the use of a 50-bp DNA ladder (Invitrogen ${ }^{\mathrm{TM}}$ ).

The polymorphism identified by the ISSR technique was tabulated according to the presence (1) or absence (0) of bands. Each ISSR band was considered a single and bi-allelic locus, with an amplifiable allele and one null allele. The GenAlex Software 6.5 (Peakall and Smouse, 2012) was used to generate the genetic distance matrix according to the methods described by Nei (1972) and to calculate Nei's Genetic Diversity $\left(\hat{H}_{\mathrm{E}}\right)$ and percentage of polymorphic loci (PLP).

Estimates of genetic differentiation between populations were calculated from the parameters, $G_{S T}$ (Nei, 1973), and by analysis of molecular variance (AMOVA - $\Phi_{S T}$ ) (Excoffier et al., 1992) using the GenAlex 6.5 software (Peakall and Smouse, 2012). The Popgene 1.31 sofware (Yeh et al., 1999) was used to calculate the $G_{S T}$ parameter.

A genetic distance matrix was generated by the GenAlex 6.5 software (Peakall and Smouse, 2012) and MEGA5 (Tamura et al., 2011) was used to generate a dendrogram of genetic similarity on the basis of the unweighted pair group method with arithmetic average (UPGMA) algorithm.

Table 2. List of primers, sequences, number of loci, and polymorphic loci.

\begin{tabular}{llcr}
\hline Primer & Sequence & Ta $\left({ }^{\circ} \mathrm{C}\right)$ & No. of cycles \\
\hline$\# 1$ & ACACACACACACACACT & 50 & 35 \\
$\# 2$ & GAGAGAGAGAGAGAGAT & 50 & 35 \\
$\# 834$ & AGA GAG AGA GAG AGA GYT & 50 & 35 \\
$\# 851$ & GTG TGT GTG TGT GTG TYG & 50 & 35 \\
$\# 860$ & TGT GTG TGT GTG TGT GRA & 50 & 35 \\
$\# 866$ & CTC CTC CTC CTC CTC CTC & 50 & 35 \\
\hline
\end{tabular}

$R=(A, G) ; Y=(C, T)$. 


\section{RESULTS AND DISCUSSION}

The set of ISSR primers used in this study generated 93 loci, with a mean number of 11.5 loci per primer, ranging from 9 (UBC \#866) to 14 (\#851 UBC) (Table 3). Of the observed loci, 10 $(10.8 \%)$ were monomorphic and $83(89.255 \%)$ were polymorphic, revealing high genetic variability between the individuals.

Table 3. Diversity estimates from the individual primers and three regions evaluated.

\begin{tabular}{|c|c|c|c|c|c|c|}
\hline & LN & PL & ML & $\hat{H}_{\mathrm{E}}$ & $G_{S T}$ & $N_{\mathrm{m}}$ \\
\hline UBC\#1 & 15 & 14 & 1 & - & - & - \\
\hline UBC\#2 & 17 & 14 & 3 & - & - & - \\
\hline UBC\#834 & 21 & 17 & 4 & - & - & - \\
\hline UBC\#851 & 16 & 16 & 0 & - & - & - \\
\hline UBC\#860 & 15 & 14 & 1 & - & - & - \\
\hline UBC\#866 & 9 & 8 & 1 & - & - & - \\
\hline Region 1 & 93 & 55 (59.14\%) & 38 & $0.207^{\mathrm{NS}}$ & - & - \\
\hline Region 2 & 93 & $51(54.84 \%)$ & 42 & $0.197^{\mathrm{NS}}$ & - & - \\
\hline Region 3 & 93 & $58(62.37 \%)$ & 35 & $0.229^{\mathrm{NS}}$ & - & - \\
\hline Total & 93 & $83(89.25 \%)$ & 10 & 0.308 & 0.297 & 1.18 \\
\hline
\end{tabular}

$\mathrm{LN}=$ loci number; $\mathrm{PL}=$ polymorphic loci; $\mathrm{ML}=$ monomorphic loci; $\hat{H}_{\mathrm{E}}=$ Nei's genetic diversity; $G_{\mathrm{ST}}=$ coefficient of population differentiation; $N_{\mathrm{m}}=$ allelic flow; $\mathrm{NS}=$ not statistically significant (paired sample $t$-test).

Nei's genetic diversity $\left(\hat{H}_{\mathrm{E}}\right)$, considering the 38 individuals, was 0.308 and there was no significant difference between the $\hat{H}_{\mathrm{E}}$ values of the three evaluated regions. The absolute values were 0.207 (Region 1), 0.197 (Region 2), and 0.229 (Region 3). These results are close to those obtained in studies with dominant markers in natural populations; for example, 0.163-0.236 for Eugenia dysenterica (Zucchi, 2002), 0.25-0.29 to Polylepis australis (Julio et al., 2008), 0.11-0.26 and 0.25-o 0.42 for Hancornia speciosa (Costa et al., 2011; Martins et al., 2012), 0.30-0.42 for Acrocomia aculeata (Oliveira et al., 2012), and 0.24-0.27 for Metrodorea nigra (Moraes Filho et al., 2015). In addition, these results are much higher than those obtained for autogamous species such as Theobroma speciosum $\left(\hat{H}_{\mathrm{E}}=0.051-0.095\right.$; Giustina et al., 2014), and Coffea arabica $\left(\hat{H}_{\mathrm{E}}\right.$ =0.05-0.15; Aga et al., 2005).

Dominant markers have been frequently used in the study of plant diversity, and the PLP is one of the most common measures used as an indicator of genetic diversity in these species (Cardoso et al., 1998; Xia et al., 2007; Julio et al., 2008; Oliveira et al., 2012; Zucchi, 2012; Zhang et al., 2013; Moraes Filho et al., 2013, 2015). The ISSR method revealed considerable polymorphism among the analyzed individuals. The highest values were observed in individuals from Region 3 (62.37\%), followed by Region 1 (59.14\%), and Region 2 (54.84\%). Considering all individuals, the percentage of polymorphic loci was $89.25 \%$, which is indicative of high genetic variability between populations of the coastal region of the Pernambuco State. Costa et al. (2011) obtained 95\% polymorphic loci in 55 mangabeiras from the Sergipe State using random amplified polymorphic DNA (RAPD) markers.

Historic gene flow or the number of migrants per generation $\left(N_{m}\right)$ can be estimated indirectly via the $F_{\mathrm{ST}}$ value. This method accepts the Wright's island model (1951) and assumes equilibrium between migration and genetic drift. Thus, when the $N_{\mathrm{m}}$ values are higher to or equal to one, when the apparent gene flow is equivalent to one or more individuals migrating per generation, the gene flow effects are sufficient to counterbalance genetic drift effects and impair the divergence of populations (Wright 1951). The observed value of migrants per generation $\left(N_{\mathrm{m}}=1.18\right)($ Table 3$)$ 
suggests that, despite being isolated, the evaluated regions were connected in the past.

In the analysis of genetic similarity, individuals from Regions 1 and 3 showed greater similarity (0.8599), and individuals from Regions 2 and 3 (0.7780) were the most genetically distinct (Table 4).

\begin{tabular}{|c|c|c|c|}
\hline Region & 1 & 2 & 3 \\
\hline 1 & - & 0.8513 & 0.8599 \\
\hline 2 & $106 \mathrm{~km}$ & - & 0.7780 \\
\hline 3 & $46 \mathrm{~km}$ & $60 \mathrm{~km}$ & - \\
\hline
\end{tabular}

AMOVA is frequently used to estimate genetic differentiation between populations by the use of dominant markers, as well as the $G_{S T}$ parameter according to Nei (1973). In studies using ISSR markers, the average values of the two estimators have been shown to be quite similar (Nybom, 2004). The results obtained by AMOVA showed that most of the genetic variation $(70 \%)$ is distributed within the three regions $\left(\Phi_{C T}\right)$, and only $30 \%$ is distributed between regions $\left(\Phi_{\text {ST }}\right)$ (Table 5). These results are in agreement with the observed $G_{\mathrm{ST}}$ values $(0.297)$. H. speciosa is described as allogamous and self-incompatible. Outcrossing species, especially trees, exhibit most of their genetic diversity within their populations (Hamrick, 1990; Aagaard, 1998).

Table 5. Molecular analysis of variance (AMOVA).

\begin{tabular}{lrrrr}
\hline Source of variation & d.f. & SS & EV & \% \\
\hline Between regions, $\Phi_{\text {ST }}$ & 2 & 125.496 & 4.178 & 30 \\
Within regions, $\Phi$ Ct & 35 & 345.109 & 9.860 & 70 \\
Total & 37 & 470.605 & 14.039 & 100 \\
\hline
\end{tabular}

d.f. $=$ degrees of freedom; $S S=$ sum of squares; $E V=$ estimated variance; $\%=$ percent of total variance. ${ }^{*} \mathrm{P}<0.001$.

Analysis of the dendrogram (Figure 3) and the genetic distance matrix (data not shown) revealed the formation of two major groups. The first group contained the individuals Han 2 and Han 3 , both from Region 1, and the other group contained the remaining 36 individuals and is divided into several subgroups. The largest distance was (51\%) observed between Han 32 and Han 46 from Region 2, and the lowest distance (4\%) was between Han 18 and Han 20 from Region 1.

The best way to conserve the remaining genetic diversity of an endangered species is to maintain their original habitats and populations. In an ideal scenario, the deforestation of forest areas along the Brazilian coast should be banned, and the remaining fragments should be preserved and connected, thus facilitating their regeneration and expansion. However, due to human activity and economic pressure on these areas, in situ conservation is very difficult. Thus, ex situ conservation in germplasm banks is of great importance for the preservation of the remaining genetic variability.

The high degree of polymorphism detected by molecular characterization suggests that the genetic variability of the surviving natural populations of $H$. speciosa in Pernambuco State can provide genetic material that can be used in future efforts to improve this crop, and for the formation of germplasm banks for conservation and breeding purposes. 


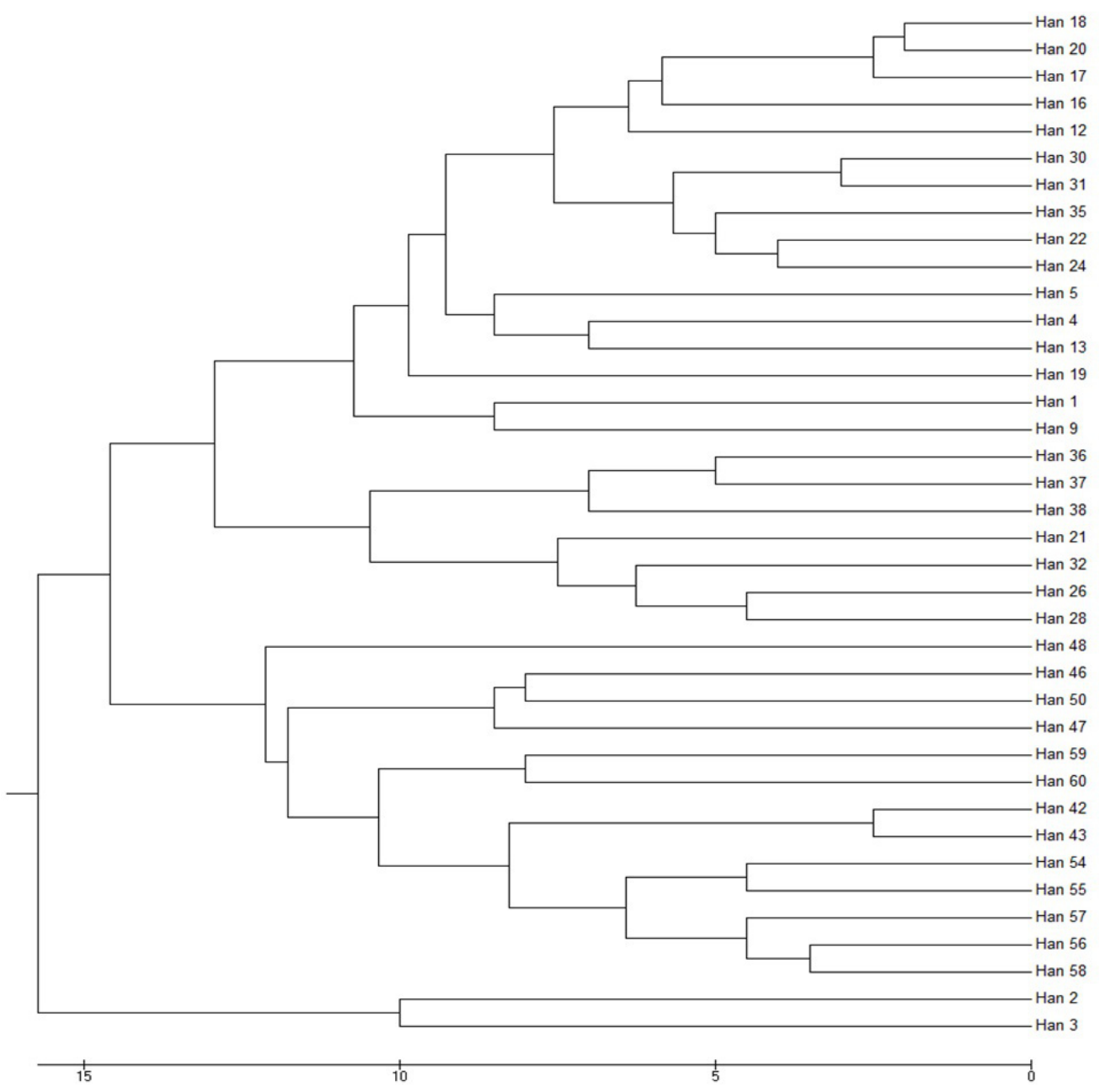

Figure 3. UPGMA dendrogram of the 38 Hancornia speciosa individuals evaluated.

\section{Conflicts of interest}

The authors declare no conflict of interest.

\section{ACKNOWLEDGMENTS}

Research supported by CAPES and UFRPE resources. H.J. Jimenez was supported by a Master Fellowship from CAPES. R.M. Moraes Filho was supported by a Doctoral Fellowship from CAPES and a Post-Doctoral Fellowship PNPD-CAPES, and A.L. Alzate-Marin was supported by a Research Assistantship from CNPq (PV \#300140/2011-8, PDS \#150737/2014-9). 


\section{REFERENCES}

Aagaard JE, Krutovskii KV and Strauss SH (1998). RAPDs and allozymes exhibit similar levels of diversity and differentiations among populations and races of Douglas fir. Heredity 81: 69-78.

Aga E, Bekele E and Bryngelsson T (2005). Inter-simple sequence repeat (ISSR) variation in forest coffee trees (Coffea arabica L.) populations from Ethiopia. Genetica 124: 213-221.

Almeida SP, Proença CEB, Sano SM and Ribeiro JF (1998). Cerrado: espécies vegetais úteis. Planaltina, DF. EMBRAPACPAC, 464.

Cardoso MA, Provan J, Powell W and Ferreira PCG (1998). High genetic differentiation among remnant populations of the endangered Caesalpinia echinata Lam. (Leguminosae Caesalpinioideae). Mol. Ecol. 7: 601-608.

Costa TS, Silva AVC, Ledo AS, Santos ARF, et al. (2011). Diversidade genética de acessos do banco de germoplasma de mangaba em Sergipe. Pesq. Agropec. Bras. 46: 499-508.

Darrault RO and Schlindwein C (2006). Polinização. In: Silva-Junior JF, Ledo, A. S.(Ed.). A Cultura da Mangaba. Embrapa Tabuleiros Costeiros, Aracaju, 43-56.

Excoffier L, Smouse PE and Quattro JM (1992). Analysis of molecular variance inferred from metric distances among DNA haplotypes: Application to human mitocondrial DNA restriction sites. Genetics 131: 479-491.

Ganga RMD, Chaves LJ and Naves RV (2009). Genetic parameters in Hancornia speciosa Gomes progenies from Cerrado. Sci. For. 37: 395-404.

Giustina LD, Luz LN, Vieira FS, Rossi FS, et al. (2014). Population structure and genetic diversity in natural populations of Theobroma speciosum Willd. Ex Spreng (Malvaceae). Genet. Mol. Res. 13: 3510-3519.

Hamrick JL (1990). Isozymes and the analysis of genetic structure in plant populations. In Isozymes in plant biology (Soltis DE and Soltis PS, eds.). Chapman \& Hall, London, 87-105.

Julio N, Sobral A, Dueñas J, Rienzo J, et al. (2008). RAPD and ISSR markers indicate diminished gene flow due to recent fragmentation of Polylepis australis woodlands in central Argentina. Biochem. Systemat. Ecol. 36: 329-335.

Kumar LS (1999). DNA markers in plant improvement: an overview. Biothechnol. Adv. 17: 143-182.

Lederman IE, Silva Junior JF, Bezerra JEF and Espindola ACM (2000). Mangaba (Hancornia speciosa Gomes) Jaboticabal, São Paulo. 35.

Martins GV, Martins LSS, Veasey EA, Lederman IE, et al. (2012). Diversity and genetic structure in natural populations of Hancornia speciosa var. speciosa Gomes in Northeastern Brazil. Rev. Bras. Frut. 34: 1143-1153.

Moraes Filho RM, Martins LSS, Musser RS, Montarroyos AV, et al. (2013). Genetic variability in accessions of the acerola germplasm bank of Universidade Federal Rural de Pernambuco, Brazil. Genet. Mol. Res. 12: 5145-5151.

Moraes Filho RM, Bonifacio-Anacleto F and Alzate-Marin AL (2015). Fragmentation effects and genetic diversity of the key semidecidual forest species Metrodorea nigra in Southwestern Brazil. Genet. Mol. Res. 14: 3509-3524.

Moura NF, Chaves LJ, Venkovsky R, Naves RV, et al. (2011). Genetic structure of mangaba (Hancornia speciosa Gomes) populations in the cerrado region of central Brazil. Biosci. J. 27: 473-481.

Murray MG and Thompson WF (1980). Rapid isolation of high molecular weight plant DNA. Nucleic Acids Res. 8: 4321-4325.

Nei M (1972). Genetic distance between populations. Am. Nat. 106: 283-292.

Nei M (1973). Analysis of gene diversity in subdivided populations. Proc. Natl. Acad. Sci. U. S. A. 70: 3321-3323.

Nei M (1978). Estimation of average heterozygosity and genetic distance from a small number of individuals. Genetics 89 : 583-590.

Nybom H (2004). Comparison of different nuclear DNA markers for estimating intraspecific genetic diversity in plants. Mol. Ecol. 13: 1143-1155.

Oliveira DA, Melo Junior AF, Brandao MM, Rodrigues LA, et al. (2012). Genetic diversity in populations of Acrocomia aculeata (Arecaceae) in the northern region of Minas Gerais, Brazil. Genet. Mol. Res. 11: 531-538.

Peakall R and Smouse PE (2012). GenAIEx 6.5: Genetic analysis in Excel. Population genetic software for teaching and research-an update. Bioinformatics. http://bioinformatics.oxfordjournals.org/content/early/2012/07/20/bioinformatics. bts460.full.pdf.

Sanguinetti CJ, Dias EN and Simpson AJG (1994). Rapid silver staining and recovery of PCR products separated on polyacrylamide gels. Biotechniques 17: 914-921.

Silva Junior JF and Ledo AS (2006). Botânica. In: A cultura da mangaba (Silva Junior JF and Ledo AS, eds.). Aracaju: Embrapa Tabuleiros Costeiros, 25-33.

Soares FP, Paiva R, Nogueira RC, Oliveira LM, et al. (2005). Cultura da mangabeira. Boletim Agropecuário, Lavras, 67: 1-12. Http:/livraria.editora.ufla.br/upload/boletim/tecnico/boletim-tecnico-67.pdf

Souza VC and Lorenzi H (2005). Botânica Sistemática: guia ilustrado para identificação das famílias de Angiospermas da flora brasileira, baseado em APG II. Ed. Instituto Platarum, Nova Odessa, 639. 
Tamura K, Peterson D, Peterson N, Stecher G, et al. (2011). MEGA5: molecular evolutionary genetics analysis using maximum likelihood, evolutionary distance, and maximum parsimony methods. Mol. Biol. Evol. 28: 2731-2739.

Wünsch A and Hormaza JI (2007). Characterization of variability and genetic similarity of European pear using microsatellite loci developed in apple. Sci. Hort. 113: 37-43.

Wright S (1951). The genetical structure of populations. Ann. Eugen. 15: 323-354.

Yeh FC, Yang R and Boyle T (1999). PopGene Version 1.31. Available at [http://www.cbiot.ufrgs.br/programas/Windows/ Biologia_molecular/PopGen32]. Accessed March 20, 2015.

Zhang L, Zhang HG and Li XF (2013). Analysis of genetic diversity in Larix gmelinii (Pinaceae) with RAPD and ISSR markers. Genet. Mol. Res. 12: 196-207.

Zietkiewicz E, Rafalski A and Labuda D (1994). Genome fingerprinting by simple sequence repeat (SSR)-anchored polymerase chain reaction amplifications. Genomics 20: 176-183.

Zucchi MI (2002). Análise da estrutura genética de Eugenia dysenterica DC utilizando marcadores RAPD e SSR. Doctoral Thesis. Escola Superior de Agricultura Luiz de Queiroz, Universidade de São Paulo. http://www.teses.usp.br/teses/ disponiveis/11/11137/tde-17032003-144316/publico/maria.pdf. Accessed March 30, 2015 